\title{
Despite some expression of folate receptor $\alpha$ in human mesothelioma cells, internalization of methotrexate is predominantly carrier mediated
}

Nushmia Z. Khokhar, MD

Alicia F. Y. Lam, BS ${ }^{a}$

Valerie W. Rusch, MD

F. M. Sirotnak, $\mathrm{PhD}^{\mathrm{a}}$

From the Program of Molecular Pharmacology and Experimental Therapeutics ${ }^{\mathrm{a}}$ and Department of Surgery, ${ }^{\mathrm{b}}$ Memorial SloanKettering Cancer Center, New York, NY.

Supported in part by National Cancer Institute grants CA08748 and CA55617.

Received for publication July 5, 2001; revisions requested Aug 24, 2001; revisions received Sept 7, 2001; accepted for publication Sept 14, 2001.

Address for reprints: F. M. Sirotnak, PhD, Laboratory for Molecular Therapeutics, Memorial Sloan-Kettering Cancer Center, 1275 York Ave, New York, NY 10021 (E-mail: sirotnaf@mskcc.org).

J Thorac Cardiovasc Surg 2002;123:862-8

Copyright (C) 2002 by The American Association for Thoracic Surgery

0022-5223/2002 $\$ 35.00+0 \quad \mathbf{1 2 / 1 / 1 2 0 3 5 2}$

doi: $10.1067 / \mathrm{mtc} .2002 .120352$
Objective: As a response to a published report documenting some expression of folate receptor $\alpha$ in human mesothelioma, studies were carried out examining the role of this receptor versus that of the reduced folate carrier in the internalization of folate analogs in this neoplasm.

Methods: Influx measurements of tritiated methotrexate were carried out in 4 mesothelioma cell lines, and 2 additional cell lines were used as comparators. Relative gene-expression analysis for the carrier and receptor gene was done by using real-time reverse transcriptase-polymerase chain reaction in the above-mentioned cell lines and mesothelioma tumor tissues obtained from patients.

Results: Internalization of tritiated methotrexate in mesothelioma cell lines grown at physiologic folate levels was carrier mediated rather than receptor mediated. Influx of this model permeant by these cells exhibited characteristics of carrier-mediated membrane transport and was only minimally reduced by the addition of $5 \mu \mathrm{mol} / \mathrm{L}$ folic acid, a concentration of this natural folate that would have completely inhibited influx by the folate receptor. Gene-expression analysis revealed prominent expression of the folate receptor in some but not all mesothelioma cell lines, and in only one case was expression of this receptor gene greater than expression of the reduced folate carrier gene. Similar analysis of human mesothelioma tumor tissue showed that, with few exceptions, receptor gene expression was substantially less than that for the carrier gene.

Conclusion: In view of the ongoing reduced folate carrier-mediated internalization that occurs in mesothelioma cells, these results would seem to argue against a role for the folate receptor in the internalization and cellular pharmacokinetics of methotrexate and other classic folate analogs in this neoplasm. Identifying the mediated route for internalization of these agents in tumor cells is a prerequisite for improving their structural design.

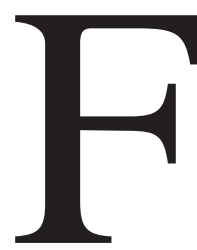

olate compounds, including folate analogs, are internalized by mammalian cells through either carrier-mediated ${ }^{1-3}$ or receptor-mediated ${ }^{4,5}$ processes. The former uses binding to a mobile carrier at the plasma membrane surface and mediates bidirectional flux. The latter uses much higher affinity binding at the membrane surface to a receptor protein that more slowly mediates unidirectional flux after internalization of the receptor-folate compound complex in the manner of many other receptor-ligand processes. ${ }^{6,7}$ The extent to which receptor-mediated processes contribute to net internalization of folates and their analogs in tumor cells remains controversial ${ }^{4}$ but will depend on the level of expression of the corresponding gene vis-à-vis the reduced folate carrier gene $(R F C 1)$ in any specific cell type. Translo- 
cation through the plasma membrane of folate analogs by the $R F C l$ carrier-mediated process is what is commonly found in tumor cells..$^{1-3}$ Because this process is much more efficient ${ }^{5,8}$ than receptor-mediated translocation, the relative level of expression required for the latter to contribute significantly to net intracellular accumulation in tumor cells is proportionally greater, particularly in the case of folate analogs. Net intracellular accumulation of folate compounds in tumor cells also reflects the operation of one or more members of the canalicular multiorganic anion transporter (cMOAT/MRP) family of adenosine triphosphatases, ${ }^{9,10}$ which extrude these compounds through the plasma membrane. However, this aspect of the cellular pharmacokinetics of folate analogs is outside the focus of the current presentation.

Folate analogs have shown ${ }^{11-13}$ interesting clinical activity against human mesothelioma, a neoplasm found, for the most part, to be relatively unresponsive to most cytotoxic agents. ${ }^{11,12}$ In view of these clinical findings and other results ${ }^{14}$ showing that the folate receptor $\alpha$ gene (FRA) is expressed in human mesothelioma but not in normal pleural mesothelium and the suggestion ${ }^{14}$ that this expression may be relevant to the responsiveness of this human neoplasm to folate analogs, it was of interest to determine to what extent receptor-mediated versus carrier-mediated processes might actually account for the internalization of these folate analogs in human mesothelioma. We addressed this question at both the biochemical and the molecular levels. Our results showed that human mesothelioma cell lines predominantly internalized a model permeant (tritiated methotrexate) by means of a carrier-mediated mechanism, ostensibly encoded by the RFCl gene, with little, if any, receptor-mediated internalization. They also showed that expression of the FRA gene in these cell lines and in patient-derived mesothelioma was almost always substantially less than expression of the $R F C l$ gene. These results are presented below.

\section{Materials and Methods}

\section{Cell Lines and Transport Measurements}

Mesothelioma cell lines were cultured in RPMI medium in accordance with procedures published earlier. ${ }^{15,16}$ The VAMT-1 and JMN cell lines were generously provided by Dr B. Gerwin in the laboratory of Dr Curtis Harris at the National Cancer Institute (Bethesda, Md). The MESO 9 and MESO 10 cell lines were generously provided by Dr S. Jhanwar and the SKOV-3 (ovarian cancer) by Dr D. Spriggs (both at Memorial Sloan-Kettering Cancer Center, New York, NY). CCRF-CEM (acute lymphoblastic leukemia) and TSU-PR1 (prostate cancer) cells were obtained from the American Type Culture Collection and cultured in RPMI medium, as described earlier. ${ }^{15,16}$ Measurement of ${ }^{3} \mathrm{H}$ methotrexate influx was carried out by procedures described in detail previously. ${ }^{1,2,15,16}$ Before the measurements of influx were carried out, the cells were grown to late logarithmic phase either in $2.2 \mu \mathrm{mol} / \mathrm{L}$ folic acid or for 2 transfer generations in $20 \mathrm{nmol} / \mathrm{L}$ dIL5-formyl tetrahydrofolate. The cells were resuspended in $0.2 \mathrm{~mL}$ of $\mathrm{HMO}$ buffer with $7 \mathrm{mmol} / \mathrm{L}$ D-glucose in 1.5-mL Eppendorf tubes, and transport experiments were carried out by incubating cells with 2 $\mu \mathrm{mol} / \mathrm{L}$ radioactive folate analog ${ }^{3} \mathrm{H}$ methotrexate at $37^{\circ} \mathrm{C}$ for varying time intervals. Parallel experiments were conducted in the presence and absence of 5 or $100 \mu \mathrm{mol} / \mathrm{L}$ folic acid.

\section{Quantitative Reverse Transcriptase-Polymerase Chain Reaction Analysis}

Total RNA was prepared with Trizol reagent (Gibco BRL; Life Technologies, Rockville, Md) from all the tumor cell lines. Firststrand complementary DNA was prepared by using the Superscript System (Gibco BRL). Mesothelioma tumor samples were harvested from patients at the time of surgical resection and snapfrozen in liquid nitrogen. Messenger RNA was purified from these tissue samples by using the Quick Prep mRNA Purification Kit (Amersham Pharmacia Biotech Inc, Piscataway, NJ) and then reverse transcribed by using M-MLV RT and random hexamers (Gibco BRL). RFC1 and FRA gene expression was quantified with the aid of an ABI Prism 7700 Sequence Detection System (TaqMan; PE Biosystems, Foster City, Calif). With the nuclease activity of Taq Polymerase, this method is based on the displacement and cleavage of a labeled fluorogenic probe specific to the target sequence flanked by polymerase chain reaction (PCR) primers. This allows the quantitation of target genes while PCR is in the log phase of amplification. A detailed description of this methodology has been previously provided. ${ }^{17}$ The primer and probe sets were designed with Primer Express Software (Applied Biosystems, Foster City, Calif), and the sequences are as follows: RFC1, forward 5'-CCGCGGCTCCTACCAGTT-3', reverse 5'-AAGACCAGGG CACAGAGCTCTT-3', probe 6FAM-ATTCTGAACACCGTCG CTTGGAAGACACT-TAMRA; $F R A$, forward 5'-GAGCAATGG TGGGAAGATTGTC-3', reverse 5'-CTCCCACTGCGCACTTG TTA-3', probe 6FAM-AACCCTGAAGTCCAGTTCCAGCCCTT GT-TAMRA; and $\beta$-actin, forward 5'-CTGGCACCCAGCACAA TG-3', reverse $5^{\prime}$-GCCGATCCACACGGAGTACT-3', probe 6FAM-TCAAGATCATTGCTCCTCCTGAGCGC-TAMRA.

Relative quantitation was done by using the comparative threshold cycle $\left(\mathrm{C}_{\mathrm{T}}\right)$ method. The $\mathrm{C}_{\mathrm{T}}$ indicates the fractional cycle number at which the amplified target reaches a fixed threshold. The amount of target gene (RFC1 and FRA) normalized to an endogenous reference $(\beta$-actin) is given as follows:

$$
2^{-\Delta \mathrm{CT}}, 18-20
$$

where $\Delta \mathrm{C}_{\mathrm{T}}$ is $\mathrm{C}_{\mathrm{T}}$ for the target gene minus $\mathrm{C}_{\mathrm{T}}$ for the reference gene. Serial dilutions of a control cDNA were run in triplicate, amplifying $\beta$-actin to generate a standard curve (Figure 1). The slope of this curve is used for calculating the run efficiency. The relation is given as follows:

$$
\mathrm{E}=10^{-1 / \mathrm{s}}-1
$$

where $\mathrm{E}$ is the efficiency and $\mathrm{S}$ is the slope. In our hands the efficiency of all runs was greater than 0.975 , with a correlation coefficient of 0.998 or greater.

\section{Tissues and Clinical Database}

Surgical specimens were obtained from consecutive patients undergoing thoracotomy and surgical resection. They were divided 


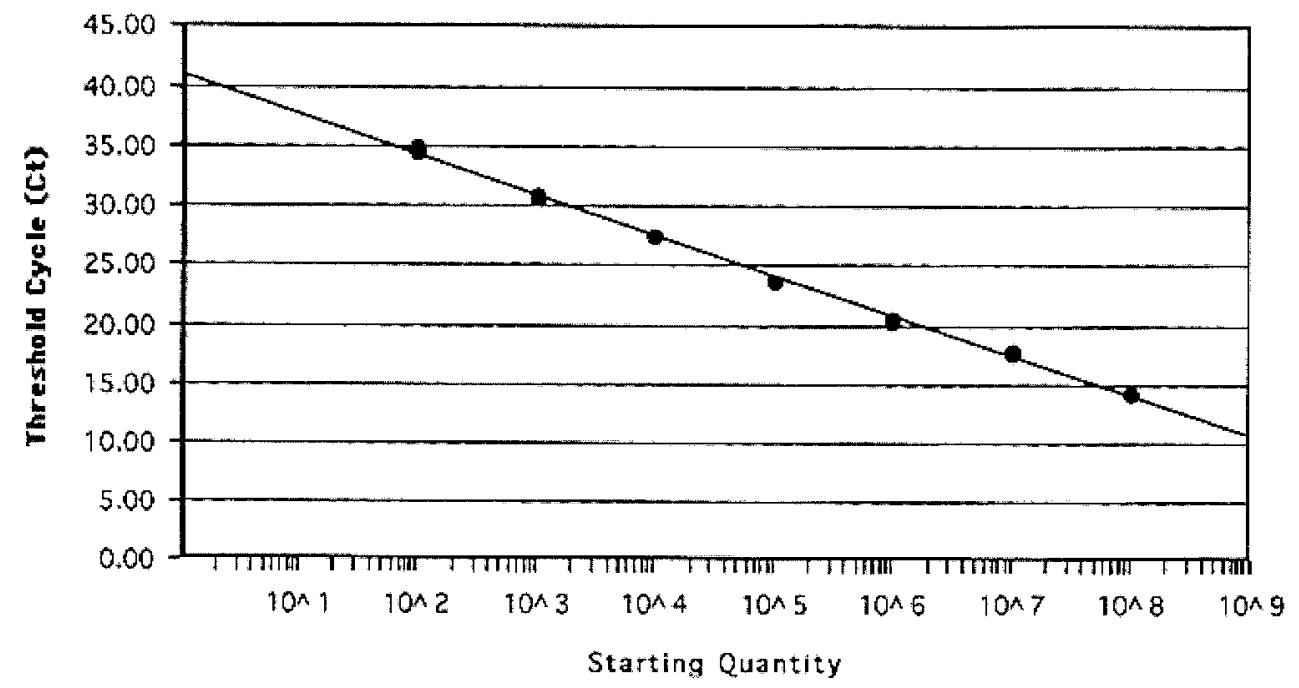

Figure 1. Standard curve of $C_{\mathrm{T}}$ value against log of starting quantity of $\beta$-actin. Dots represent standard samples plotted in triplicate. The slope is -3.37 , and the correlation coefficient is $\mathbf{0 . 9 9 8}$.

into small samples $(3 \times 3 \times 3 \mathrm{~mm})$, snap-frozen, and stored at $-140^{\circ} \mathrm{C}$. Histologic sections were reviewed by a pathologist to identify those tumor samples that had predominantly tumor cells among nucleated cells on the slide. Relevant clinical data were collected for all the patients and linked to the specimens, and the link-up to patient identifiers was destroyed by the Tumor Bank before distribution to this project to protect patient confidentiality. Tissue collection and these experiments were performed in accordance with the guidelines of Memorial Sloan-Kettering Cancer Center.

\section{Materials}

Samples of ${ }^{3} \mathrm{H}$ methotrexate were obtained from Moravek Biochemicals, Inc (Brea, Calif). This and all other folate compounds were purified by means of high-performance liquid chromatography to greater than $98 \%$ purity. ${ }^{21}$ All other chemicals were reagent or molecular biology grade.

\section{Results}

The results of experiments measuring the mediated internalization of ${ }^{3} \mathrm{H}$ methotrexate by 4 human mesothelioma cell lines are given in Figure 2 and Table 1. The results obtained with VAMT-1 cells are compared in Figure 1 with those obtained with CCRF-CEM and SKOV-3 cells. In each case the time course for internalization obtained with 2 $\mu \mathrm{mol} / \mathrm{L}{ }^{3} \mathrm{H}$ methotrexate was consistent with that expected for an RFC1-mediated process. ${ }^{1,2}$ Internalization was initially rapid and constant, with time followed by an exponential approach to steady state (influx = efflux). Moreover, the addition of $5 \mu \mathrm{mol} / \mathrm{L}$ folic acid to the cell suspension, an extremely effective inhibitor of FRA-mediated, but not RFC1-mediated, internalization, ${ }^{1-5}$ had only a minimal effect on these time courses. However, influx could be inhibited by a much higher concentration $(100 \mu \mathrm{mol} / \mathrm{L})$ of folic acid, a result consistent with a role for $R F C l$ in the inter- nalization of ${ }^{3} \mathrm{H}$ methotrexate in these cells. These results were similar to those obtained (Figure 2 and Table 1) with the other mesothelioma cell lines and the CCRF-CEM and SKOV-3 cell lines, which were used as comparators. Again, the data in Table 1 show only a slight effect of $5 \mu \mathrm{mol} / \mathrm{L}$ folic acid on influx of ${ }^{3} \mathrm{H}$ methotrexate. The same results after folic acid addition were obtained when the cells were grown in $2.2 \mu \mathrm{mol} / \mathrm{L}$ folic acid or $20 \mathrm{nmol} / \mathrm{L}$ dIL5-formyl tetrahydrofolate, a concentration approximating the physiologic level of folate in human blood. Because FRA has an extremely high affinity $\left(\mathrm{K}_{\mathrm{m}}=1 \pm 0.2 \mathrm{mmol} / \mathrm{L}\right)$ for this natural folate, whereas $R F C 1$ has extremely low affinity $\left(\mathrm{K}_{\mathrm{m}}=100 \pm 20 \mu \mathrm{mol} / \mathrm{L}\right)$, these results clearly implicate RFCl as the predominant, if not exclusive, route for mediated internalization of ${ }^{3} \mathrm{H}$ methotrexate in VAMT-1 cells, as is the case for CCRF-CEM ${ }^{1}$ and SKOV-3 cells.

As an adjunct to the studies described above, we also examined, for the purpose of comparison, these human mesothelioma cell lines, as well as CCRF-CEM and SKOV-3 cells, for the expression of both FRA and RFCI genes by using real-time quantitative reverse transcriptasePCR (RT-PCR), with $\beta$-actin as the reference comparator gene (Figure 3). The data in Figure 4 show that expression of these genes was extremely variable over a wide range. In only one case (MESO 10) was expression of FRA equal to or higher than that of $R F C 1$. Moreover, expression of $R F C 1$ appeared to show (Table 1) a general correlation with influx of ${ }^{3} \mathrm{H}$ methotrexate in these cells. Influx was lowest in the case of MESO 9 and MESO 10 and highest in the case of VAMT-1, the cell lines with the least and greatest expression of the RFCl gene, respectively. The single discrepancy between the rate of internalization and RFCl gene expres- 

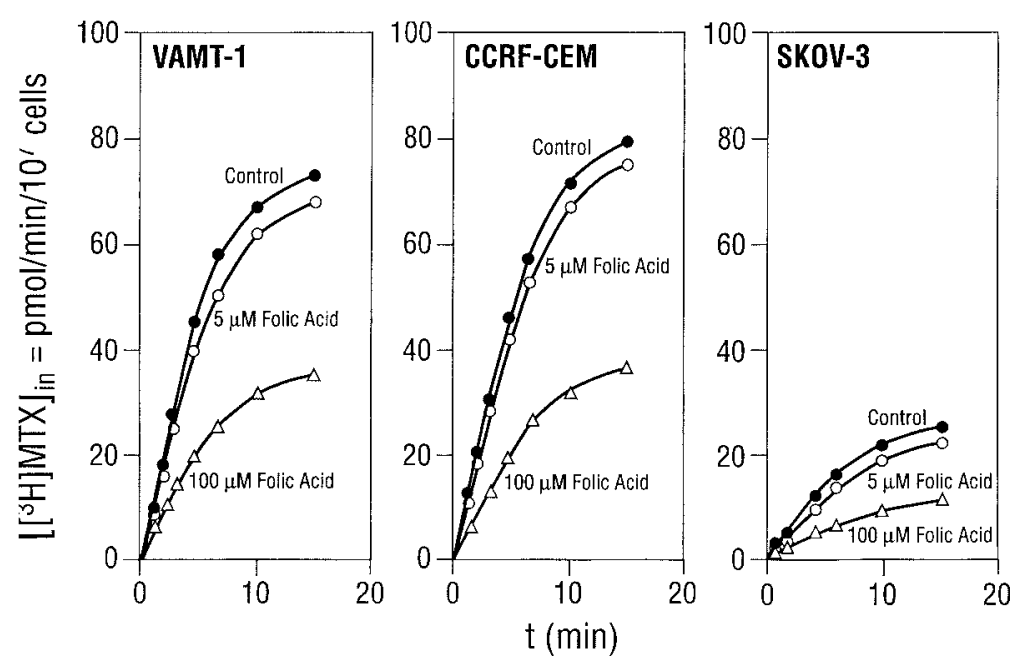

Figure 2. Time course for internalization of ${ }^{3} \mathrm{H}$ methotrexate in various human tumor cells. Cells were incubated with $2 \mu \mathrm{mol} / \mathrm{L}{ }^{3} \mathrm{H}$ methotrexate (MTX) with or without $5 \mu \mathrm{mol} / \mathrm{L}$ folic acid in $50 \mathrm{mmol} / \mathrm{L}$ HEPES and $180 \mathrm{mmol} / \mathrm{L}$ sucrose brought to $\mathrm{pH} 7.4$ with $\mathrm{MgO}$. Aliquots of cell suspensions were removed at the indicated times for processing. Additional details are provided in the text. Average of 3 experiments with SEM $\pm 20 \%$ or less.

TABLE 1. Internalization of ${ }^{3} \mathrm{H}$ methotrexate by human mesothelioma, CCRF-CEM, SKOV-3, and TSU-PR1 cells in the presence and absence of $5 \mu \mathrm{mol} / \mathrm{L}$ folic acid

\begin{tabular}{|c|c|c|c|c|}
\hline \multirow[b]{2}{*}{ Cell type } & \multirow[b]{2}{*}{ Histopathology } & \multicolumn{2}{|c|}{ Influx velocity (pmol/min per $10^{7}$ cells) } & \multirow[b]{2}{*}{ Relative RFC1 expression } \\
\hline & & No folic acid & $5 \mu \mathrm{mol} / \mathrm{L}$ folic acid & \\
\hline CCRF-CEM & ALL & $9.1 \pm 2$ & $9.1 \pm 1$ & 50 \\
\hline VAMT-1 & Mesothelioma & $8.8 \pm 2$ & $8.4 \pm 1$ & 43 \\
\hline JMN & Mesothelioma & $5.8 \pm 1$ & $4.9 \pm 1$ & 15 \\
\hline TSU-PR1 & Prostate carcinoma & $3.7 \pm 0.8$ & $3.5 \pm 1$ & 7 \\
\hline MESO-10 & Mesothelioma & $2.6 \pm 0.4$ & $2.4 \pm 0.3$ & 4 \\
\hline SKOV-3 & Ovarian carcinoma & $2.5 \pm 0.4$ & $2.2 \pm 0.3$ & 15 \\
\hline MESO-9 & Mesothelioma & $2.4 \pm 0.5$ & $2.2 \pm 0.5$ & 3 \\
\hline
\end{tabular}

One to $2 \times 10^{6}$ cells $/ \mathrm{mL}$ grown in physiologic folate were incubated for 1 to 6 minutes at $37^{\circ} \mathrm{C}$ with $2 \mu \mathrm{mol} / \mathrm{L}^{3} \mathrm{H}$ methotrexate in $\mathrm{HMO}$ buffer in the presence and absence of $5 \mu \mathrm{mol} / \mathrm{L}$ folic acid. Additional experimental details are given in the text. Data are average of 3 experiments \pm SEM.

sion occurred with SKOV-3 cells. However, in this case, and to some extent with the other tumor cell lines, functional expression of the $R F C 1$ gene could also reflect differences in the rate of translation of RFCl mRNA. The results with SKOV-3 cells, showing that FRA gene expression was far greater than for $R F C 1$, was of interest given the finding that ${ }^{3} \mathrm{H}$ methotrexate internalization in these cells was relatively low and apparently $R F C l$ mediated. The level of expression of FRA in SKOV-3 cells was even higher than that found in all the other tumor cells included here in a parallel analysis. It is known that high expression of FRA is a common occurrence in ovarian cancer cells. ${ }^{9}$ The results obtained with SKOV-3 cells, for which there is companion transport data (Figure 2), are strikingly consistent with the accepted notion that receptor-mediated internalization of ${ }^{3} \mathrm{H}$ methotrexate is much less efficient than carrier-mediated internalization.
The same RT-PCR analysis was carried out (Figure 5) with a large number of mesothelioma specimens obtained from patients during surgical resection of tumors. These data also revealed highly variable expression of both $R F C 1$ and FRA genes. However, with few exceptions, levels of expression for $F R A$ were very substantially lower than those for $R F C l$. The data also show that there were no appreciable differences observed (Figure 5) in the level of expression of either gene among tumors with epitheloid or mixed (epitheloid-sarcomatoid) histologic features. Only one of the available samples was pure sarcomatoid in origin and was included because $R F C l$ gene expression in this sample was exceptionally high compared with expression of FRA.

\section{Discussion}

$F R A$ - and carrier-mediated transport of folate compounds in mammalian cells are readily distinguishable by the avidity 


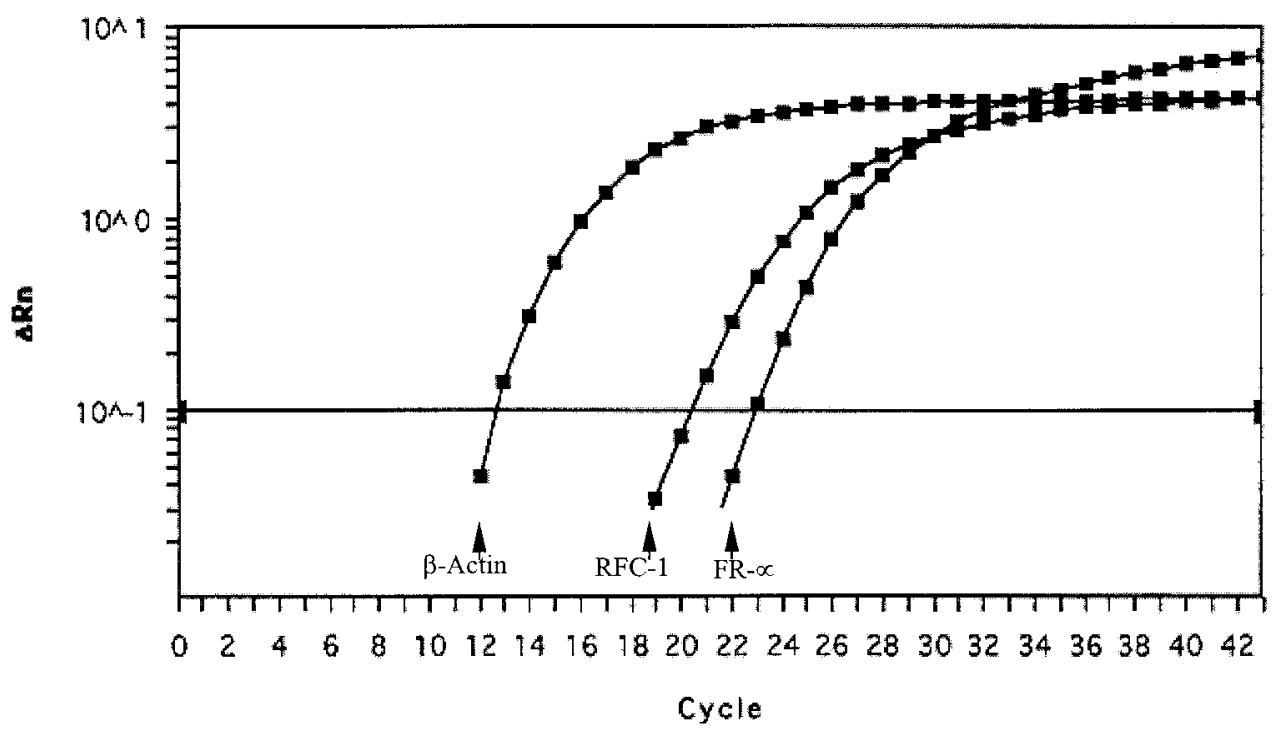

Figure 3. Real-time RT-PCR determinations of FRA and RFC1 gene expression in the VAMT-1 human mesothelioma cell line. $\Delta \boldsymbol{R}_{n}$ represents the normalized fluorescence signal minus the baseline signal established in the first few cycles of PCR. $C_{T}$ represents the fractional cycle number at which an increase in the reporter fluorescence above a set threshold (horizontal black line) is first detected. $\beta$-Actin gene expression was used as a control to normalize these PCR reactions. These data are representative of replicate runs. Additional details are given in the text.

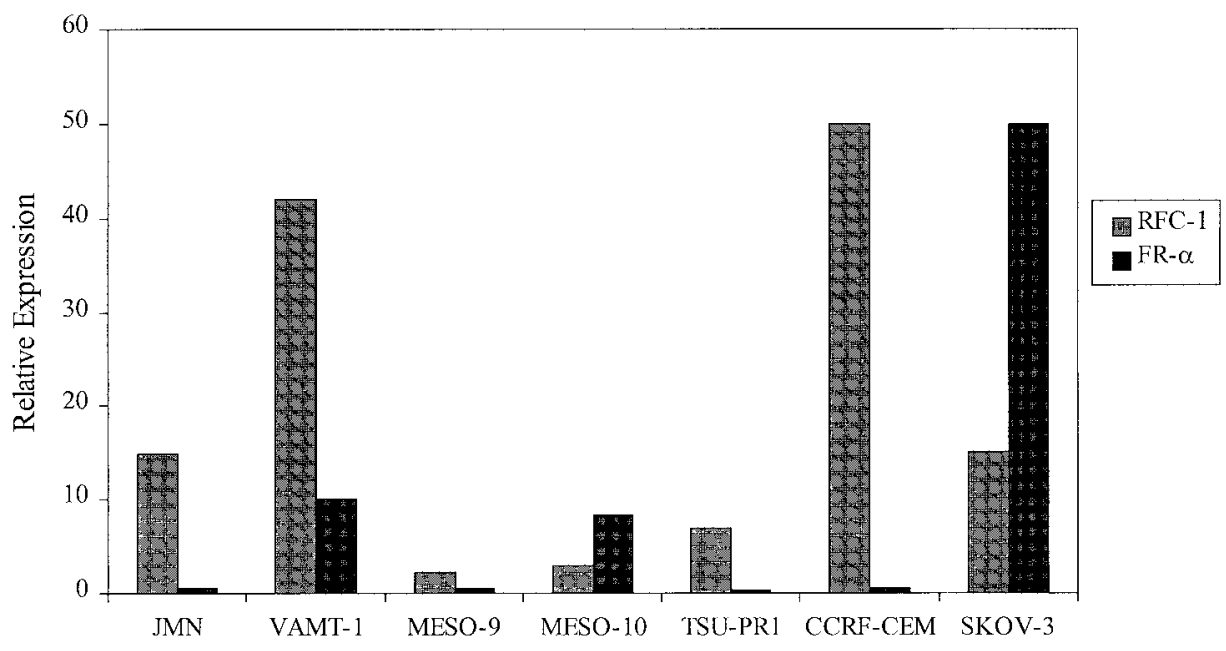

Figure 4. Relative levels of RFC1 and FRA mRNA expression in various cell lines. The $y$ axis scale is in relative units (specific target mRNA relative to $\beta$-actin mRNA expression).

of the receptor- or carrier-permeant interaction..$^{1-5}$ Binding of these compounds by FRA occurs with an affinity several orders of magnitude greater than binding by the RFCl folate carrier. Moreover, in the case of folic acid itself, binding to $R F C 1$ is approximately 2 orders of magnitude less than for substituted reduced folates or folate analogs, ${ }^{3}$ which have influx $\mathrm{K}_{\mathrm{m}}$ or $\mathrm{K}_{\mathrm{i}}$ values in the low micromolar range. For all other transporters described, ${ }^{1-4}$ the affinity for all these folate compounds is similar and in the low micromolar range. Thus the relative inability of folic acid to inhibit internalization of competing, structurally similar permeants in tumor cells is a defining characteristic of $R F C l$-mediated transport. We have taken advantage of these differences to delineate $F R A$ - versus $R F C 1$ - mediated internalization of ${ }^{3} \mathrm{H}$ methotrexate in these mesothelioma cell lines.

The physiologic or pharmacologic significance of FRA gene expression in mesothelioma is not understood nor is it understood in ovarian carcinoma, the only example of highlevel expression in patient-derived material. ${ }^{22}$ Despite this high level of expression of FRA in ovarian cancer cells, 
earlier studies from our laboratory ${ }^{16}$ and, more recently, elsewhere, ${ }^{23}$ as well as our studies described here, have documented internalization of folate compounds exclusively as a carrier-mediated process in these cells in culture, as well as for patient-derived ovarian cancer cells. Our findings showed that internalization of ${ }^{3} \mathrm{H}$ methotrexate in the 4 mesothelioma cell lines examined was also predominantly $R F C 1$ mediated. Because of the relative inefficiency of receptor-mediated versus $R F C 1$-mediated internalization, ${ }^{1-6}$ the low to modest level of expression of this receptor observed here in mesothelioma cells has no effect on total intracellular accumulation of this folate analog, as shown by the actual measurements of ${ }^{3} \mathrm{H}$ methotrexate influx. The situation with regard to gene expression was similar in those mesothelioma cells derived directly from patients. Thus, the lack of a role for $F R A$ in the mediated internalization of folate analogs in human mesothelioma cells relates to the fact that both gene expression and transport efficiency of $F R A$ is considerably less than that of RFCl in this neoplasm.

The documentation of overexpression of the FRA gene in mesothelioma compared with in normal adjacent tissue is not sufficient to conclude that FRA has a role in making this tumor susceptible to antifolates. The previous study ${ }^{14}$ making this observation failed to look at the corresponding $R F C 1$ level of expression. Our studies, on the other hand, compared the level of expression of both genes and also carried out transport experiments in mesothelioma cell lines, clearly showing primarily carrier-mediated internalization of ${ }^{3} \mathrm{H}$ methotrexate. This information is of importance if $\mathrm{RFCl}$ gene expression is to be used as a molecular marker for clinical response to folate analogs in this human neoplasm and as a focus for new efforts at designing more efficacious analogs. Prospective studies focusing on the former question will need to be carried out in the context of clinical trials of newer folate analogs to establish the relevance of $R F C l$ gene expression. Such a trial examining the efficacy of a new 10-deazaaminopterin analog (10-propargyl-10-deazaaminopterin) is currently in progress. ${ }^{24}$

\section{References}

1. Sirotnak FM. Obligate genetic expressing in tumor cells of a fetal membrane property mediating folate transport: biological significance and implications for improved therapy of human cancer. Cancer Res. 1985;45:3992-4000.

2. Goldman ID, Matherly LH. The cellular pharmacology of methotrexate. In: Goldman ID, editor. Membrane transport of antineoplastic agents. Int Encycl Pharmacol Therapeutics. 1986;118:283-302.

3. Sirotnak FM, Tolner B. Carrier-mediated membrane transport of folates in mammalian cells. Ann Rev Nutr. 1999;19:91-122.

4. Ratnam M, Freisheim JH. Proteins involved in the transport of folates and antifolates by normal and neoplastic cells: In: Picriano MF, editor. Folate metabolism in health and disease. New York: Wiley-Liss; 1992. p. 91-120.

5. Kamen BA, Capdevila A. Receptor-mediated folate accumulation is regulated by the cellular folate content. Proc Natl Acad Sci U S A. 1986;83:5983-7.

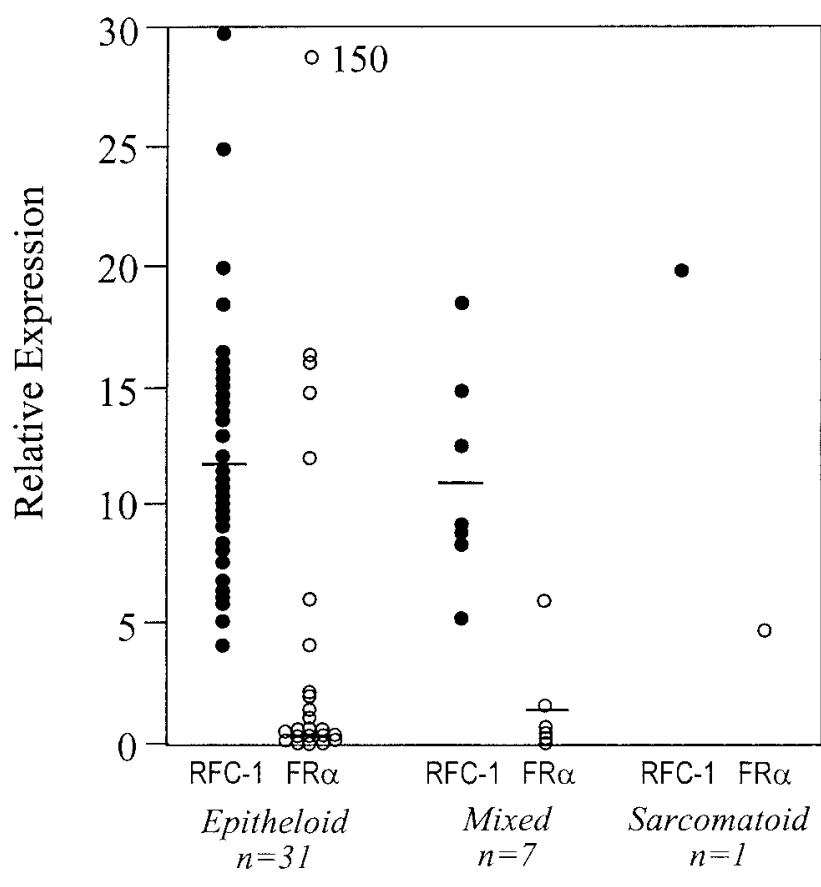

Figure 5. Relative levels of RFC1 and FRA expression in mesothelioma tumor samples on the basis of their histologic subtypes. The $y$ axis scale is in relative units (specific target mRNA relative to $\beta$-actin mRNA expression).

6. Anderson RG, Kamen BA, Rothberg KG. Potocytosis: sequestration and transport of small molecules by caveolae. Science. 1992;255: 410-1.

7. Smart EJ, Foster DC, Ying YS, Kamen BA, Anderson RG. Protein kinase $\mathrm{C}$ activators inhibit receptor-mediated potocytosis by preventing internalization of caveolae. J Cell Biol. 1994;124:307-13.

8. Henderson GB, Tsuji JM, Kumar HP. Mediated uptake of folate by a high-affinity binding protein in sublines of L1210 cells adapted to nanomolar concentrations of folate. J Membr Biol. 1998;101:247-58.

9. Konig J, Nies AT, Cui Y, Leier I, Keppler D. Conjugate export pumps of the multidrug resistance protein (MRP) family: localization, substrate specificity and MRP2-mediated drug resistance. Biochem Biophys Acta. 1999;1461:377-94.

10. Borst P, Evers R, Kool M, Wijnholds J. A family of drug transporers: the multidrug resistance-associated proteins. J Natl Cancer Inst. 2000; 92:1295-302.

11. Ong ST, Vogelzang NJ. Chemotherapy in malignant pleural mesothelioma. J Clin Oncol. 1996;14:1007-17.

12. Rusch VW. Pleurectomy/decortication in the setting of multimodality treatment for diffuse malignant pleural mesothelioma. Semin Thorac Cardiovasc Surg. 1997;9:367-72.

13. Kindler HL, Belani CP, Herndon JE II, Vogelzang NJ, Suzuki Y, Green MR. Edatrexate (10-ethyl-deaza-aminopterin) (NSC:626715) with or without leucovorin rescue for malignant mesothelioma. Sequential phase II trials by the cancer and leukemia group B. Cancer. 1999;86:1985-91.

14. Bueno R, Appasani K, Mercer H, Lester S, Sugarbaker D. The $\alpha$ folate receptor is highly activated in malignant pleural mesothelioma. J Thorac Cardiovasc Surg. 2001;121:225-33.

15. Sirotnak FM, DeGraw JI, Moccio DM, Goutas LJ. New folate analogs of the 10-deaza-aminopterin series. Basis for structural design and biochemical and pharmacologic properties. Cancer Chemother Pharmacol. 1984;12:18-25.

16. Moccio DM, Sirotnak FM, Samuels LL, Ahmed T, Yagoda A, DeGraw JI, et al. Similar specificity of membrane transport for folate 
analogues and their metabolites by murine and human tumor cells: a clinically directed laboratory study. Cancer Res. 1984;44:352-7.

17. Eads CA, Danenberg KD, Kawakami K, Saltz LB, Danenberg PV, Laird PW. CpG island hypermethylation in human colorectal tumors is not associated with DNA methyltransferase overexpression. Cancer Res. 1999;59:2302-6.

18. Fink L, Seeger W, Ermert L, Hänze J, Stahl U, Grimminger F, et al. Real-time quantitative RT-PCR after laser-assisted cell picking. Nat Med. 1998;4:1329-33.

19. Yuan A, Yang PC, Yu CJ, Chen WJ, Lin FY, Kuo SH, et al. Interleukin-8 messenger ribonucleic acid expression correlates with tumor progression, tumor angiogenesis, patient survival, and timing of relapse in non-small-cell lung cancer. Am J Respir Crit Care Med. 2000;162:1957-63.
20. User Bulletin \#2: ABI Prism 7700 Sequence Detection System. Perkin Elmer Corp; P/N 4303859 Rev. A, Stock No. 777802-001, 1997.

21. Samuels LL, Moccio DM, Sirotnak FM. Similar differential for total polyglutamylation and cytotoxicity among various folate analogue in human and murine tumor cell lines in vitro. Cancer Res. 1985;45:488-95.

22. Toffoli G, Cernigoi C, Russo A, Gallo A, Bagnoli M, Boiocchi M. Overexpression of folate binding protein in ovarian cancers. Int $J$ Cancer. 1997;74:193-8.

23. Corona G, Giannini F, Fabris M, Toffoli G, Boiocchi M. Role of folate receptor and reduced folate carrier in the transport of 5-methyltetrahydrofolic acid in human ovarian carcinoma cells. Int J Cancer. 1998;75:125-33.

24. Krug LM, Ng, KK, Kris MG, Miller VA, Tong W, Heelan RT, et al. Phase I and pharmacokinetic study of 10-deazaaminopterin, a new antifolate. Clin Cancer Res. 2000;6;3493-8.

Access to The Journal of Thoracic and Cardiovascular Surgery Online is reserved for print subscribers!

Full-text access to The Journal of Thoracic and Cardiovascular Surgery Online is available for all print subscribers. To activate your individual online subscription, please visit The Journal of Thoracic and Cardiovascular Surgery Online, point your browser to http://www.mosby.com/itcvs, follow the prompts to activate your online access, and follow the instructions. To activate your account, you will need your subscriber account number, which you can find on your mailing label (note: the number of digits in your subscriber account number varies from 6 to 10). See the example below in which the subscriber account number has been circled:

\section{Sample mailing label}

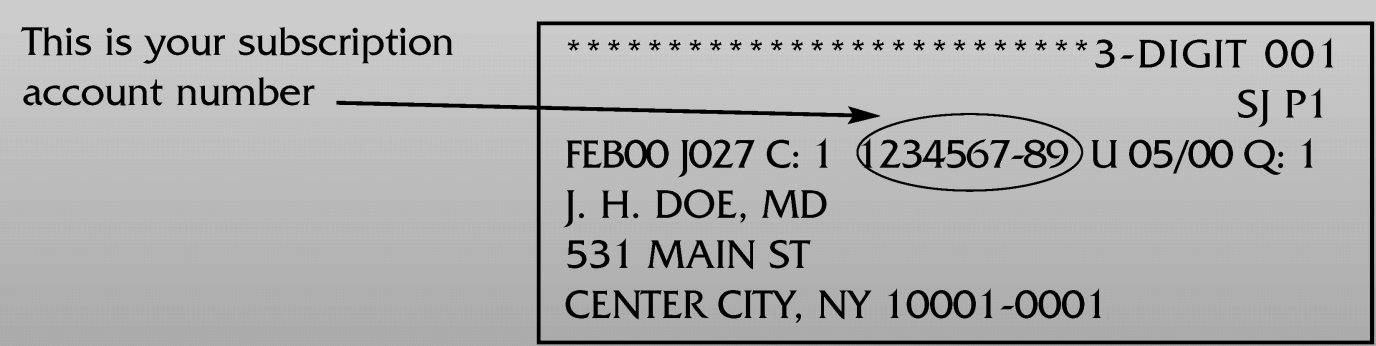

Personal subscriptions to The Journal of Thoracic and Cardiovascular Surgery Online are for individual use only and may not be transferred. Use of The Journal of Thoracic and Cardiovascular Surgery Online is subject to agreement to the terms and conditions as indicated online. 